\section{Current medical and surgical management of lung cancer}

\author{
Shereen Ajab ${ }^{1 *}$, Jack A Kastelik² and Mahmoud Loubani ${ }^{1}$ \\ 'Department of Cardiothoracic Surgery, Castle Hill Hospital, Hull University Teaching Hospitals NHS \\ Trust, University of Hull and Hull York Medical School, UK \\ ${ }^{2}$ Department of Respiratory Medicine, Castle Hill Hospital, Hull University Teaching Hospitals NHS \\ Trust, University of Hull and Hull York Medical School, UK
}

Received: 09 March, 2021

Accepted: 20 April, 2021

Published: 21 April, 2021

*Corresponding authors: Miss Shereen Ajab, MRCS, Clinical Teaching Fellow, Department of Cardiothoracic Surgery, Castle Hill Hospital, Hull University Teaching Hospitals NHS Trust, University of Hull and Hull York Medical School, UK,

E-mail: shereen.ajab@nhs.net

Keywords: Minimally invasive surgery; Bronchoscopy; Endobronchial ultrasound; Endoscopic ultrasound; Non-small cell lung cancer; Segmentectomy; Phototherapy; Radiotherapy; Chemotherapy; Immunotherapy

https://www.peertechzpublications.com

\section{Abbreviations}

CT: Computer Tomography; EBUS TBNA: Endobronchial Ultrasound-guided Transbronchial Needle Aspiration; FDG:Fluorodeoxyglucose; IALT: International Adjuvant Lung Cancer Trial; LDCT: Low Dose Computer Tomography; NSCLC: Non-Small Cell Lung Cancer; PET: Positron Emission Tomography; RATS: Robot-Assisted Thoracic Surgery; SABR: Stereotactic Ablative Body Radiotherapy; TKI: Tyrosine Kinase Inhibitor; VATS: Video-Assisted Thoracic Surgery

Lung cancer is the most commonly diagnosed malignancy and a leading cause of cancer related deaths accounting for 1.8 million deaths worldwide in 2018 [1]. In recent years, the investigation and management of lung cancer has significantly changed with emerging evidence that rapid investigations may improve survival. For example, the randomised controlled trial, LungBOosT compared conventional diagnosis and staging to endobronchial ultrasound-guided transbronchial needle aspiration (EBUS-TBNA) following staging Computer Tomography (CT). The trial demonstrated that the patients in the EBUS group received a treatment decision twice as fast as patients in the conventional diagnosis and staging group with increased median survival and in a subgroup of patients who underwent surgery there was reported higher postoperative survival [2]. In the UK, the National Optimal Lung Cancer Pathway was introduced to reduce variations amongst practice, expedite investigations and speed up diagnosis and treatment3. The pathway commences with a fast-track clinic for patients with suspected lung malignancy and will result in a CT of the thorax for those patients who were found to have an abnormal chest radiograph [3]. Accurate staging is then vital as this guides treatment options and ultimately determines prognosis [4]. Major changes in the lung cancer pathway include the widespread introduction of the Positron Emission Tomography (PET) scans for mediastinal and hilar nodal staging and has allowed for this to become the first diagnostic and staging investigation for patients potentially suitable for curative treatment [3]. The gold standard for pre-operative mediastinal lymph node staging is still mediastinoscopy with reported sensitivity of $81.8 \%$ (95\% CI:63-82) and accuracy of up to $97 \%$ with the advantage of providing samples for histological analysis [5]. Mediastinoscopy is recommended for Fluorodeoxyglucose (FDG) avid nodes or lymph nodes larger than $1 \mathrm{~cm}$ in the short axis [2]. Another less invasive approach to lymph node sampling includes the use of the endobronchialultrasound guided transbronchial needle aspiration [2]. Endobronchial ultrasound in combination with endoscopic ultrasound is reported to have a diagnostic accuracy of 97\% [6]. A randomised control trial demonstrated greater sensitivity in detecting nodal metastases using endo-sonography and surgical staging (94\% sensitivity) compared with surgical staging alone (79\% sensitivity) [7].

Another important development is the wider acceptance of the lung cancer screening programmes. The National Lung Screening Trial in the US demonstrated a $20 \%$ reduction in mortality associated with lung cancer in patients screened with low dose CT (LDCT)[8]. The screening trial NELSON randomised patients to LDCT for lung cancer screening and compared this with chest radiography in the control arm [9]. The majority of lung malignancies were identified at an (earlier) stage 1 in the group screened with LDCT $(69.4 \%)$ compared with less than $10 \%$ of lung cancer cases diagnosed in stage 1 in the control arm 
[9]. Lung cancer screening has also resulted in the detection of increased numbers of peripheral pulmonary lesions [10]. These lesions were historically sampled using CT needle biopsy, however over the last ten years advances in interventional pulmonology have resulted in a movement towards the use of modalities such as radial EBUS and navigational bronchoscopy [10]. Radial EBUS utilises a transducer which rotates $360^{\circ}$ and can be inserted through the bronchoscopic working channel, which allows for obtaining high resolution, real time images of lesions surrounding the airways [10]. The use of the radial probe provides the advantage over flexible bronchoscopy of allowing visualisation of distal small airways with greater diagnostic yield, which was reported to range between 56 to $78 \%$ [1012]. Minimally invasive technology such as electromagnetic navigational bronchoscopy and virtual bronchoscopy have also demonstrated high diagnostic yield for pulmonary lesions. Virtual bronchoscopy produces reconstructed 3D images of the airways using thin slice CT imaging and in combination with the radial probe EBUS has shown to further increase diagnostic yield to $94.4 \%$ and allowed for $77 \%$ of peripheral pulmonary lesions to be localised [10,13-15]. Electromagnetic navigational bronchoscopy uses an electromagnetic emitter and tracking board to create external magnetic fields for bronchoscopic guidance [16]. A 4-D map is produced using the navigational software and the CT images allow for the flexible bronchoscope with a sensor probe to localise the lesions $[13,15]$. Following localisation brushings and biopsies can be performed by removing the probe and inserting instruments through a sheath [15]. The prospective, multicentre, cohort study NAVIGATE reported a median planning time of 5 minutes and procedure specific time of 25 minutes for electromagnetic navigational bronchoscopy with a 12-month diagnostic yield of $73 \%$ and low rate of procedural complications [17].

Current treatment options for Non-Small Cell Lung Cancer (NSCLC) include surgery, phototherapy, chemotherapy, radiotherapy and immunotherapy.Advances in the surgical management of lung cancer have aimed to preserve lung function with minimal trauma and enhanced post-operative recovery [18]. VIDEO-ASSISTED THORACIC SURGERY (VATS) lobectomy has been the gold standard surgical approach for early stage non-small cell lung cancer for more than 30 years. In certain cases there is evidence to support parenchymal sparing procedures including sub-lobar resections in the form of segmentectomy [19]. Segmentectomy has been accepted as a surgical approach for ground glass opacity dominant early stage non-small cell lung cancer and is associated with a good prognosis [20]. The use of segmentectomy for solid dominant lung tumours with radical intent however remains controversial [21]. A recent meta-analysis of 28 studies has shown superior results with VATS lobectomy compared with segmentectomy for tumours in stage I and IA whereas there were no significant differences in oncological outcomes (hazard ratios, overall survival and cancer-specific survival) in tumours less than $2 \mathrm{~cm}$ [20]. A recent metanalysis demonstrated a higher risk of recurrence in the segmentectomy group compared with lobectomy though there was no statistical difference observed in overall survival [21]. To date there are three randomised control trials that compare lobectomy with segmentectomy.
Ginsberg and Rubinstein concluded that limited pulmonary resection was associated with higher locoregional recurrence and mortality compared with lobectomy [22]. More recent randomised trials however have reported no difference in postoperative measures including major complications and 30 and 90 day mortality between patients having undergone lobectomy versus segmentectomy $[23,24]$. Technological developments resulted in introduction of robot-assisted thoracoscopic surgery (RATS), which provides an option for a minimally invasive thoracic surgical approach with evidence of improved short-term outcomes compared with VATS and no significant difference in five-year overall survival [25]. Robotic surgery allows for greater precision and manoeuvrability as evidenced by the results of a propensity matched study comparing robotic to open lobectomy, which showed an increase in median node evaluation with robotic resection [26].

Another aspect of lung cancer management that has recently developed includes patients with stage II to III nonsmall cell lung cancer who are considered fit post-surgical resection where adjuvant chemotherapy is recommended and those with early stage lung cancer who are not deemed fit to undergo surgery. Thus, the use of adjuvant chemotherapy has been shown by the International Adjuvant Lung Cancer Trial (IALT) to provide $44.5 \%$ survival benefit at 5 years compared with $40.4 \%$ survival benefit at 5 years in the observation cohort post resection [27]. Moreover, the results of the ANITA trial demonstrated an $8.7 \%$ benefit in 5-year disease free survival in patients receiving adjuvant Cisplatin and Vinorelbine, with the greatest benefit in patients with stage IIIa disease at $16 \%$ [28]. Whilst surgery remains first line treatment an alternative therapeutic option is in the form of radical external beam radiotherapy with evidence that it offers high local control rates and low toxicity [29]. In fact, Stereotactic ablative body radiotherapy (SABR) has become the standard of care for inoperable early stage lung cancer located peripherally and less than $5 \mathrm{~cm}$ in maximum diameter [29]. In addition to SABR there are other thermal ablative modalities including laser, radiofrequency ablation (RFA), microwave ablation and cryoablation which have a role in the management of NSCLC [20]. The most commonly used laser Nd-YAG allows for coagulation and vaporisation used in combination with a flexible or rigid bronchoscope [30]. Microwave ablation has potential advantages over RFA including larger ablation zones and can used for lesions close to vascular structures with a reduced heat sink effect [31]. Cryoablation, a relatively novel modality, utilizes pressurized argon gas to destroy tumour cells through creating an environment around $-140^{\circ} \mathrm{C}$, while allowing for good visualisation of the ablation zone under imaging guidance and preservation of the collagenous architecture of the tissue [32]. Laser, argon plasma coagulation, electrosurgery and cryoablation all have a role in providing relief from airway obstruction secondary to endoluminal malignancy [30]. Photodynamic therapy has a role in the management of patients with early-stage lung cancer deemed unsuitable for surgery. Photodynamic therapy exposes tumour cells to light of a specific wavelength causing photosensitisation and destruction of the malignant cells [33]. In addition, it has a role in the multi-modal management of non-small cell lung cancer 
with demonstrable palliative efficacy and safety for patients with airway obstruction due to advanced malignancy [34]. Clinical trials are currently assessing the efficacy and safety of novel photosensitizers including water-soluble palladiumbacteriochlorophyll and Fotolon[34].

Despite wider use of advanced staging modalities including PET scanning and EBUS there still remains a small proportion of patients in whom lung cancer upstaging is reported on resection pathology who may require additional treatment options. The recent National Comprehensive Cancer Network guidelines recommend the use of sequential or concurrent chemoradiotherapy for patients with IIIA-N2 disease and R1 resection and concurrent chemotherapy for $\mathrm{R} 2$ resection which has been demonstrated to improve overall survival[35]. Locally advanced NSCLC therefore demands a multimodality approach in the form of concurrent chemo-radiotherapy, however the prognosis remains poor with a median survival of up to 28 months $[36,37]$. Patients that are unlikely to tolerate the substantial toxicity of concurrent chemo-radiotherapy can be offered a sequential approach with accelerated radiotherapy resulting in an improved overall survival and an absolute benefit of $2.5 \%$ at 5 years compared to conventional schedules [38]. Radiotherapy also has a role in palliative management of advanced and metastatic lung cancer offering symptomatic relief and improvement in quality of life.

There are some variations in treatment options of lung cancer. For example, treatment of potentially resectable stage III NSCLC is variable with a recent national UK survey demonstrating a preference for surgical management and adjuvant chemotherapy for patients with stage III N2 single station disease where a lobectomy could be offered. In patients where a pneumonectomy would be required and for multi-station N2 disease patients were commonly offered chemoradiotherapy [39]. However, the approach to systemic anticancer therapy for advanced non-small cell lung cancer is becoming more standardised although the increasing number of therapeutic options including immunotherapy has made it more complex.

Advances in immunotherapeutic agents for NSCLC stem from studies investigating the immune checkpoint pathways with a substantial focus on the programmed death-1 (PD1) pathway comprised of the $\mathrm{PD}-1$ receptor and reciprocal ligands programmed death-ligand 1 (PD-L1) and programmed death-ligand 2 (PD-L2)[40]. In addition, the cytotoxic T-lymphocyte antigen-4 (CTLA-4) pathway has also been heavily studied [40]. These studies have led to a new group of agents available for the treatment on NSCLC by targeting these pathways, the immune checkpoint inhibitors, which allow the intrinsic immune response to protect against tumour antigens through an uninhibited $\mathrm{T}$ cell response [40]. Currently, first line therapy for tumours that express PDL1 on immunohistochemistry analysis is Pembroluzimab, second line therapy is Nivolumab and Atezolizumab and for patients with disease deemed unresectable, Durvalumab has been approved for maintenance therapy [41]. The IMpower 150 study demonstrated significant improvement in both progression-free survival and overall-survival in patients with metastatic non squamous non-small cell lung cancer receiving Atezolizumab and Bevacizumab in addition to chemotherapy (Carboplatin and Paclitaxel)[42]. Progression free survival was 8.3 months in patients receiving Atezolizumab, Bevacizumab, Carboplatin and Paclitaxel compared with 6.8 months for those receiving the same combination without Atezolizumab, with a median overall survival of 19.2 months compared with 14.7 months respectively [42].

Patients that are not fit enough to tolerate combination chemotherapy and immunotherapy can be offered single agent immunotherapy or standard chemotherapy. All patients with a new diagnosis of advanced non-small cell lung cancer require testing for germline mutations including EGFR, ALK and Ros1 mutations. Tyrosine kinase inhibitors (TKI) are first line for these cases, with a recent meta-analysis demonstrating favourable efficacy of Osimertinib with regards to progression free survival and overall survival compared with other EGFRTKIs with less toxicity [43]. In patients with ALK or ROS-1 mutations Crizotinib has shown a longer progression-free survival at 7.7 months compared with only 3.3 months for patients that received chemotherapy [44]. Emerging resistance to TKIs including Crizotinib has led to the search for further options and new-generation selective inhibitors are being studied [45].

\section{Conclusion}

The last decade has seen tremendous growth in the investigations and therapeutic options for patients with lung cancer. There have been significant surgical developments including minimally invasive thoracic surgery as well advances in the medical treatments for lung cancer with a focus on more targeted therapies with less systemic toxicity. For this reason a multi-disciplinary approach remains vital for the optimal management of patients with lung cancer and remains one of the most important driving forces responsible for better outcomes in these patients.

\section{References}

1. Bray F, Ferlay J, Soerjomataram I, Siegel R, Torre L, et al. (2018) Global cancer statistics 2018: GLOBOCAN estimates of incidence and mortality worldwide for 36 cancers in 185 countries. CA: A Cancer Journal For Clinicians 68: 394 424. Link: https://bit.ly/3eeGaNL

2. Navani N, Nankivell M, Lawrence D, Lock S, Makker H, et al. (2015) Lung cance diagnosis and staging with endobronchial ultrasound-guided transbronchial needle aspiration compared with conventional approaches: an open-label, pragmatic, randomised controlled trial. Lancet Respir Med 3: 282-289. Link: https://bit.ly/3x8JxOS

3. National Optimal Lung Pathway- cancerresearchuk.org Link: https://bit.ly/3syqSbJ

4. Crombag L, Dooms C, Stigt J, Tournoy K, Schuurbiers O, et al. (2019) Systematic and combined endosonographic staging of lung cancer (SCORE study). Eur Respir J 53: 1800800. Link: https://bit.ly/3ssHv8I

5. Sivrikoz C, Ak I, Simsek F, Döner E, Dündar E (2011) Is Mediastinoscopy Still the Gold Standard to Evaluate Mediastinal Lymph Nodes in Patients with Non-Small Cell Lung Carcinoma?. Thorac Cardiovasc Surg 60: 116-121. Link: https://bit.ly/3tzV7jS 
6. Liberman M, Sampalis J, Duranceau A, Thiffault V, Hadjeres R, et al. (2014) Endosonographic Mediastinal Lymph Node Staging of Lung Cancer. Chest 146: 389-397. Link: https://bit.ly/3dzKfwK

7. Annema JT, van Meerbeeck JP, Rintoul RC, Dooms C, Deschepper E, et al. (2010) Mediastinoscopy vs endosonography for mediastinal nodal staging of lung cancer: a randomized trial. JAMA 304: 2245-2252. Link: https://bit.ly/3sz7viT

8. National Lung Screening Trial Research Team, Aberle DR, Adams AM, Berg CD, Black WC, Clapp JD, et al. (2011) Reduced lung-cancer mortality with lowdose computed tomographic screening. N Engl J Med. 365: 395-409. Link: https://bit.ly/3enbLwS

9. Yousaf-Khan $U$, van der Aalst $C$, de Jong $P$, Heuvelmans $M$, Scholten $E$, et al. (2016) Final screening round of the NELSON lung cancer screening trial: the effect of a 2.5-year screening interval. Thorax 72: 48-56. Link: https://bit.ly/3ne7QXf

10. Dhillon SS, Harris K (2017) Bronchoscopy for the diagnosis of peripheral lung lesions. J Thorac Dis 9: S1047-S1058. Link: https://bit.ly/2P2opbl

11. Steinfort D, Khor $Y$, Manser R, Irving L (2010) Radial probe endobronchial ultrasound for the diagnosis of peripheral lung cancer: systematic review and meta-analysis. Eur Respir J 37: 902-910. Link: https://bit.ly/2QF4ksu

12. Steinfort DP, Vincent J, Heinze S, Antippa P, Irving LB (2011) Comparative effectiveness of radial probe endobronchial ultrasound versus CTguided needle biopsy for evaluation of peripheral pulmonary lesions: a randomized pragmatic trial. Respiratory Medicine 105: 1704-1711. Link: https://bit.ly/3n2ql0m

13. Khan KA, Nardelli $P$, Jaeger $A$, O'Shea $C$, Cantillon-Murphy $P$, et al. (2016) Navigational Bronchoscopy for Early Lung Cancer: A Road to Therapy. Advances in Therapy 33: 580-596. Link: https://bit.ly/3apHsEB

14. Asano F, Shinagawa N, Ishida T, Tsuzuku A, Tachihara M, et al. (2015) Virtual bronchoscopic navigation improves the diagnostic yield of radialendobronchial ultrasound for peripheral pulmonary lesions with involved bronchi on CT. Internal Medicine (Tokyo, Japan) 54: 1021-1025. Link: https://bit.ly/32rllrE

15. Asano F, Eberhardt R, Herth FJ (2014) Virtual bronchoscopic navigation fo peripheral pulmonary lesions. Respiration; International Review of Thoracic Diseases 88: 430-440. Link: https://bit.ly/3xbSCGw

16. Belanger AR, Akulian JA (2017) An update on the role of advanced diagnostic bronchoscopy in the evaluation and staging of lung cancer. Ther Adv Respir Dis.11: 211-221. Link: https://bit.ly/3tzloh4

17. Khandhar SJ, Bowling MR, Flandes J, Gildea TR, Hood KL, et al. (2017) Electromagnetic navigation bronchoscopy to access lung lesions in 1,000 subjects: first results of the prospective, multicenter NAVIGATE study. BMC Pulm Med 17: 59. Link: https://bit.ly/3n1dtYB

18. Yang SM, Hsu HH, Chen JS (2017) Recent advances in surgical management of early lung cancer. J Formos Med Assoc 116: 917-923. Link: https://bit.ly/3n9ToiL

19. Bilgi Z, Swanson SJ (2019) Current indications and outcomes for thoracoscopic segmentectomy for early stage lung cancer. J Thorac Dis 11: S1662-S1669. Link: https://bit.ly/3tu6Lg5

20. Winckelmans T, Decaluwé H, De Leyn P, Van Raemdonck D (2020) Segmentectomy or lobectomy for early-stage non-small-cell lung cancer: a systematic review and meta-analysis. Eur J Cardiothorac Surg 57: 10511060. Link: https://bit.ly/3dyFH9P

21. Rao S, Ye L, Min L, Zhao G, Chen Y, et al. (2019) Meta-analysis of segmentectomy versus lobectomy for radiologically pure solid or soliddominant stage IA non-small cell lung cancer. J Cardiothorac Surg 14: 197. Link: https://bit.ly/3sA9lun
22. Ginsberg RJ, Rubinstein LV (1995) Randomized trial of lobectomy versus limited resection for T1 N0 non-small cell lung cancer. Lung Cancer Study Group. Ann Thorac Surg 60: 615-623. Link: https://bit.ly/2QlkB61

23. Suzuki K, Saji H, Aokage K, Watanabe SI, Okada M, et al. (2019) Comparison of pulmonary segmentectomy and lobectomy: Safety results of a randomized trial. J Thorac Cardiovasc Surg 158: 895-907. Link: https://bit.ly/3dAkVH7

24. Altorki NK, Wang X, Wigle D, Gu L, Darling G, et al. (2018) Perioperative mortality and morbidity after sublobar versus lobar resection for early-stage non-small-cell lung cancer: post-hoc analysis of an international, randomised, phase 3 trial (CALGB/Alliance 140503). The Lancet. Respiratory Medicine 6: 915-924. Link: https://bit.ly/2Pa4kAw

25. Montagne F, Bottet B, Sarsam M, Mbadinga F, Chaari Z, et al. (2020) Robotic versus open and video-assisted thoracoscopic surgery approaches for lobectomy. Mini-Invasive Surgery Link: https://bit.ly/3tyyz33

26. Upham T, Onaitis M (2018) Video-assisted thoracoscopic surgery versus robot-assisted thoracoscopic surgery versus thoracotomy for early-stage lung cancer. J Thorac Cardiovasc Surg 156: 365-368. Link: https://bit.ly/32uZ6Cm

27. Arriagada R, Bergman B, Dunant A, Le Chevalier T, Pignon JP, et al. (2004) Cisplatin-based adjuvant chemotherapy in patients with completely resected non-small-cell lung cancer. New England Journal of Medicine 350: 351-360. Link: https://bit.ly/3ekHoXw

28. Douillard JY, Rosell R, De Lena M, Carpagnano F, Ramlau R, et al. (2006) Adjuvant vinorelbine plus cisplatin versus observation in patients with completely resected stage IB-IIIA non-small-cell lung cancer (Adjuvant Navelbine International Trialist Association [ANITA]): a randomised controlled trial. The Lancet. Oncology 7: 719-727. Link: https://bit.ly/2P4rEiV

29. Murray P, Franks K, Hanna GG (2017) A systematic review of outcomes following stereotactic ablative radiotherapy in the treatment of early-stage primary lung cancer. Br J Radiol 90: 20160732. Link: https://bit.ly/3tB98xB

30. Baine MJ, Sleightholm R, Neilsen BK, Oupický D, Smith LM, et al. (2019) Stereotactic Body Radiation Therapy Versus Nonradiotherapeutic Ablative Procedures (Laser/Cryoablation and Electrocautery) for Early-Stage NonSmall Cell Lung Cancer. J Natl Compr Canc Netw 17: 450-458. Link: https://bit.ly/3x8Gfeo

31. Das SK, Huang YY, Li B, Yu XX, Xiao RH, et al. (2020) Comparing cryoablation and microwave ablation for the treatment of patients with stage IIIB/IV nonsmall cell lung cancer. Oncol Lett 19: 1031-1041. Link: https://bit.ly/2OGocM1

32. Sonntag PD, Hinshaw JL, Lubner MG, Brace CL, Lee FT (2011) Thermal ablation of lung tumors. Surg Oncol Clin N Am 20: 369-ix. Link: https://bit.ly/3v5Mo9y

33. Moan J, Berg K (1992) Photochemotherapy of cancer: experimental research. Photochem Photobiol 55: 931-948. Link: https://bit.ly/3tM73ik

34. Wang K, Yu B, Pathak JL (2021) An update in clinical utilization of photodynamic therapy for lung cancer. J Cancer 12: 1154-1160. Link: https://bit.ly/3syv779

35. Yuan M, Men Y, Kang J, Sun X, Zhao M, et al. (2021) Postoperative radiotherapy for pathological stage IIIA-N2 non-small cell lung cancer with positive surgical margins. Thoracic Cancer 12: 227-234. Link: https://bit.ly/3xc8Pf5

36. Aupérin A, Le Péchoux C, Rolland E, Curran WJ, Furuse K, et al. (2010) Metaanalysis of concomitant versus sequential radiochemotherapy in locally advanced non-small-cell lung cancer. J Clin Oncol 28: 2181-2190. Link: https://bit.ly/3dzPgp4

37. Yoon SM, Shaikh T, Hallman M (2017) Therapeutic management options for stage III non-small cell lung cancer. World J Clin Oncol 8: 1-20. Link: https://bit.ly/3arhmRn

38. Mauguen A, Le Péchoux C, Saunders Ml, Schild SE, Turrisi AT, et al. (2012) Hyperfractionated or accelerated radiotherapy in lung cancer: an individual patient data meta-analysis. J Clin Oncol 30: 2788-2797. Link: https://bit.ly/3aruCFH

Citation: Ajab S, Kastelik JA, Loubani M (2021) Current medical and surgical management of lung cancer. J Surg Surgical Res 7(1): 052-056. DOI: https://dx.doi.org/10.17352/2455-2968.000137 
39. Evison M, Edwards J, McDonald F, Popat S (2020) Stage III Non-small Cell Lung Cancer: A UK National Survey of Practice. Clin Oncol 32: 527-536. Link: https://bit.ly/3aq1776

40. Suresh K, Naidoo J, Lin CT, Danoff S (2018) Immune Checkpoint Immunotherapy for Non-Small Cell Lung Cancer: Benefits and Pulmonary Toxicities. Chest 154: 1416-1423. Link: https://bit.ly/3dyKDLT

41. Lim SM, Hong MH, Kim HR (2020) Immunotherapy for Non-small Cell Lung Cancer: Current Landscape and Future Perspectives. Immune Network 20: e10. Link: https://bit.ly/2RPS1dB

42. Socinski MA, Jotte RM, Cappuzzo F, Orlandi F, Stroyakovskiy D, et al. (2018) Atezolizumab for First-Line Treatment of Metastatic Nonsquamous NSCLC. The New England Journal of Medicine 378: 2288-2301. Link: https://bit.ly/32y5poN
43. Holleman MS, Van Tinteren H, Groen HJ, AI M, Uyl-de Groot CA (2019) Firstline tyrosine kinase inhibitors in EGFR mutation-positive non-small-cell lung cancer: a network meta-analysis. OncoTargets and Therapy 12: 1413-1421. Link: https://bit.ly/3n11Ssk

44. Shaw AT, Kim DW, Nakagawa K, Seto T, Crinó L, et al. (2013) Crizotinib versus chemotherapy in advanced ALK-positive lung cancer. New England Journal of Medicine 368: 2385-2394. Link: https://bit.ly/3szaLKT

45. Katayama R, Gong B, Togashi N, Miyamoto M, Kiga M, et al. (2019) The newgeneration selective ROS1/NTRK inhibitor DS-6051b overcomes crizotinib resistant ROS1-G2032R mutation in preclinical models. Nat Commun 10: Link: https://bit.ly/3dy6Jyj
Discover a bigger Impact and Visibility of your article publication with Peertechz Publications

\section{Highlights}

* Signatory publisher of ORCID

* Signatory Publisher of DORA (San Francisco Declaration on Research Assessment)

* Articles archived in worlds' renowned service providers such as Portico, CNKI, AGRIS, TDNet, Base (Bielefeld University Library), CrossRef, Scilit, J-Gate etc.

* Journals indexed in ICMJE, SHERPA/ROMEO, Google Scholar etc.

* OAI-PMH (Open Archives Initiative Protocol for Metadata Harvesting)

* Dedicated Editorial Board for every journa

- Accurate and rapid peer-review process

* Increased citations of published articles through promotions

* Reduced timeline for article publication

Submit your articles and experience a new surge in publication services (https://www.peertechz.com/submission).

Peertechz journals wishes everlasting success in your every endeavours.

Copyright: @ 2021 Ajab S, et al. This is an open-access article distributed under the terms of the Creative Commons Attribution License, which permits unrestricted use distribution, and reproduction in any medium, provided the original author and source are credited. 